\title{
Harmonization of piece-by-piece measurement methods in all stages of roundwood manufacturing processes
}

\author{
Ziedonis Miklašēvičs \\ Rēzeknes augstskola. Address:Atbrīvošanas aleja 90, Rēzekne, LV-4601, Latvia
}

\begin{abstract}
In the sawmill industry in Latvia the roundwood represents about $70 \%$ of the total production cost. The quantity measurements of the round wood are required throughout the logic chain of wood from forest to the sawmills but inspite of a large proportion of the total cost the term "true volume" of roundwood is equally actual for supplies and processors of wood. The roundwood volume results differ measured the same load by measuring the diameters of log in short intervals using harvester measurement systems and in sawmills by measuring the diameters of $\log$ in short intervals using electronic 3D systems or measured manually using the most accurate method according to the requirements of standard LVS 82:2003 by measuring top and butt diameter. This means that it is a great interest in industry to develop the measurement methods and systems to have a lower cost and more efficient algorithm to determine the wood volume.

The purpose of this study is to compare the wood volume calculation results made by the most accurate manual and automatic measurement methods and give the recommendations for minimizing difference between them.

The research is a continuation to the work done in the project „Harmonisation of piece-by-piece measurement methods of roundwood approved by Standard LVS 82:2003 „Apaḷo kokmateriālu uzmērī̌sana” (Miklasevics, Z., 2013).
\end{abstract}

Keywords: roundwood; piece-by-piece measurement methods; volume.

\section{INTRODUCTION}

Measurement operations where wood is the subject of business are sensitive to accuracy. Different calculation methods are used in wood harvesting, sale, purchase and wood processing using manual or automatical measurements. According to technical possibilities of measurement equipment methods of wood volume calculation and approach to problems, more procedures have been proposed to determine the "true volume". Due to results in the determination of volume electronic procedures are not consistent with manual methods or with each other and their results do not correspondent to "true volume" of measured assortiments (Janak, K., 2005, Janak, K., 2007, Miklasevics, Z., 2013.)

The analyse of the measurement results obtained in Latvia sawmills where the most accurate piece-bypiece manual measurement method (2) (Fig.7.) based on the top and butt diameter measurements is being used, have shown that the volume values especially of spruce logs from neiloid zone usually are overestimated comparing to results obtained by measurement methods based on measuring diameter in short intervals using harvester measurement systems and by measuring diameter in short intervals using electronic 3D systems (Patterson, D.W.). It is explainable because of irregular form of roundwood, the volumes of logs are determined through simplified approach and the different algorithm of volume calculationare being used.

The main characteristics of each measurement method used in the investigation are sequential:

1. according to the top and butt diameter measurements by standard LVS 82:2003 (2) (Fig.8.) For calculating the log volume the neiloid-shape profile of the log assume to be a conus in zone among the top and $0.5 \mathrm{~m}$ from the butt. Butt zone $0-0.5 \mathrm{~m}$ of the log assume to be a cilinder. The algorithm of the volume (3.2.) (Fig.7.)calculation formula partly ignore the natural shape of the log. Therefore the volume values possibly are overerestimated.

2. by measuring diameter in short intervals using harvester measurement systems.

There are couple of different formulas for calculating the log volume by harvester bucking computer (Circular VMR 1-99). In Finland only cylinder formula is used in practice. Other possible volume calculation formulas are truncated cone, Nilson (Estonian), Huber and Smalian (Räsänen, T., 2007, Reg 918/66/97). The corresponding variables related to the investigation are defined below: 

(cm)

$\operatorname{DBH}\left(\mathrm{d}_{1,3}\right)$ - diameter at $1.3 \mathrm{~m}$ from felling cut

Spp-file - $\quad$ stem prediction parameters

StanFordstandard- Standard for Forestry Data and Communication

Ktr-file -

harvester calibration and control measurement file. Sent from digital callipers to (onboard) merchandishing (bucking) computer, and from merchandishing computer to the office computer

Prd-file - production of the harvester (measurement certificate)

Pri-file - production-individual. Data of each $\log$ made from the site.

The volume calculation (V1) of the first 1.3 meter part (3.2.) (Fig.7.) of the butt log is calculated a bit differently from the other logs. Calculation based on extrapolated butt diameter. Diameter of butt end on butt logs $(0.0-1.3 \mathrm{~m})$ is estimated on the height of $1.3 \mathrm{~m}$ from felling cut based on measured diameter $\operatorname{DBH}\left(\mathrm{d}_{1,3}\right)$. Calculation carried out based on either functions or tables (Černy, M., 1995., EN 1309-2. 2006., Wood,G.B. and Wiant, H.V. 1995). Volume of 0.0-1.3 m section (starting from butt-end of first $\log$ ) is usually calculated in 1 to $10 \mathrm{~cm}$ steps. Diameters for those points are estimated as a function of $\operatorname{DBH}\left(\mathrm{d}_{1,3}\right)$ or actually diameter at $1.3 \mathrm{~m}$ distance from cutting point (Fig. 1.).Tables and functions give the extrapolation coefficient of a certain point as a result of measured diameter at $\operatorname{DBH}\left(\mathrm{d}_{1,3}\right)$ and distance (height) of the extrapolation point from the point of the felling cut.The measured diameter at reference height multiplied with the given coefficient will give the extrapolated diameter. Volume of butt end using these estimated diameters is to be done in the same way as the upper part of the log. Harvesters could use either tables or functions depending on their present method or processing capacity. The coefficients given in tables are based on specific taper curve and stump height models for pine, spruce and birtch separately and have been developed by Metsäteho ("Spp-file in StanForD” (Räsänen, 2007.)). In Finland it is a legal requirement to use the function. In Latvia it is possible to use the function in all major harvester systems but it depends on the market whether it is activated in harvester and computer caliper although it is known that there might be some deviations in the stem profiles for certain areas.

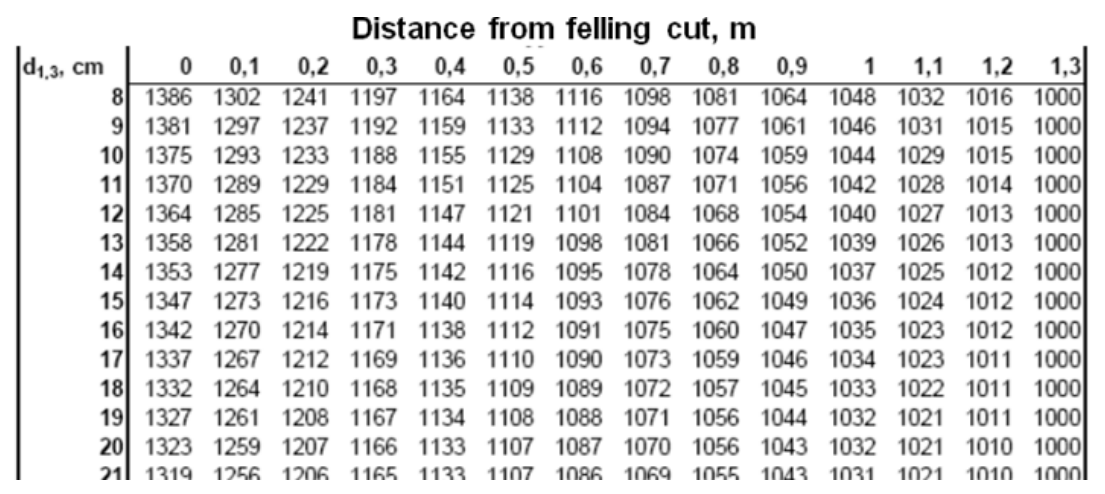

Fig. 1. The example of extrapolation coefficient table for pine using $130 \mathrm{~cm}$ as reference height (coefficients for butt end profile, \%) (Räsänen, T., Poikela, A., Arlinger, J. 2007.)

The analyse of the measurement results obtained in Latvia sawmills where measurement methods are based on measuring diameter in short intervals using electronic 3D systems have shown that especially neiloid-shape profile of the logs butt end is not predicted well enough by using harvester measuring systems. The main reasons which cause these differences in harvester measurement systems are sequent.

Different calculation methods are used in harvesters for extrapolating butt end diameter values from the first measured values:

1. Different harvester head models start diameter measuring at different heights.

2. Falsely extrapolated diameter values lead to incorrect volumes of the butt end.
3. Incorrect volume values are the sequence of incorrectly estimated volumes of the butt end diameter.

Harvester measurerement system algorithm used in investigation based on functions defined in Spp file (Räsänen, 2007.).

3. by measuring diameter in short intervals using electronic 3D systems (3.1.) (Fig.8.).

There are no legislative norm that would determine the requirements for methods of processing the measured data and methods of calculating the logs volume in Latvia sawmills. The algorithm of the volume calculation using 3D scanner Mikropuu Oy (FIN) by measuring diameter in short intervals is given (3.1.) (Fig.8.). 
according to the top and butt diameter measurements by model of volume calculation developed for Swedish roundwood systems (3.1.) (Fig.8.) (Anon 2000).

In Sweden as the most accurate piece-by-piece measurement method based on the algorithm model of the formula were developed for roundwood of Scots pine (Pinus silvestris) and Norway spruce (Picea abies) (Anon 2000). The formula were obtained from 10751 logs from middle and southern Sweden measured in sections and at the small $(10 \mathrm{~cm}$ from top) and large end (50 cm from large end for butt logs and $10 \mathrm{~cm}$ from large end for other logs).

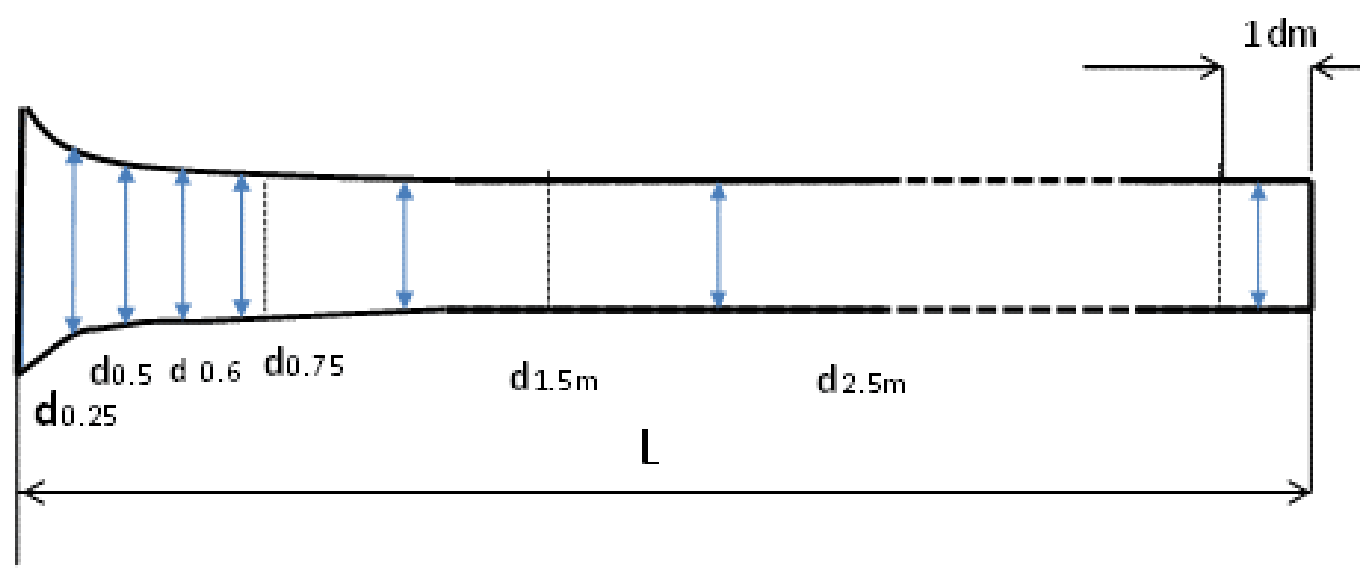

Fig.2. Control measuring points for developing of the volume calculation algorithm

The data needed for developing the volume calculation algorithm was prepared according to the measurement scheme (Fig.2.). The first diameter measurement taken at $25 \mathrm{~cm}$ from the log butt means that the most but not all buttress volume is included in the volume.

The calculation algorithm bases on „2" constant which redistributes the weight of those two diameters so that the small end diameter gets a larger influence on the diameter that represents the log in the formula. According to investigations made in Sweden (Anon 2000, Nylinder, M., 2010) predict the volume of roundwood obtained by measuring sections by using the small and large end diameter and lenght of the log will give more accurate volume results comparing to other manual measuring methods. The algorithm of the volume calculation formula is based on the natural shape of the log. Therefore measurement method is being chosen as the reference formula in this investigation.

The purpose of this study is to assess the wood volume calculation results made by the proposed manual, harvester and electronic measurement:

1. according to the top and butt diameter measurements by model of volume calculation developed for Swedish roundwood (Anon 2000),

2. according to the top and butt diameter measurements (LVS 82:2003),

3 . by measuring diameter in short intervals using harvester measurement systems,

4. by measuring diameter in short intervals using electronic 3D systems and by analyzing the reasons of difference of the results to find and to prove that the industrial implementation of the most appropriate manual measurement method which provide the least roundwood volume deviation comparing to the results given by harvester and electronic measurement is feasible.

\section{MATERIALS AND METHODS}

The study was carried out in March 2014 in the region Kurzeme in Latvia. Large buttress of the first $\log$ of the stem causes the wide dispersions of the measurement results. The wood felling area (Fig. 3.) was chosen (As)-Myrtillosa mel.(Woodlands on drained mineral) because of the shape of spruce stems with large buttress. The wood falling time was chosen because of the minimal risk of debarking in the process of harvesting. 

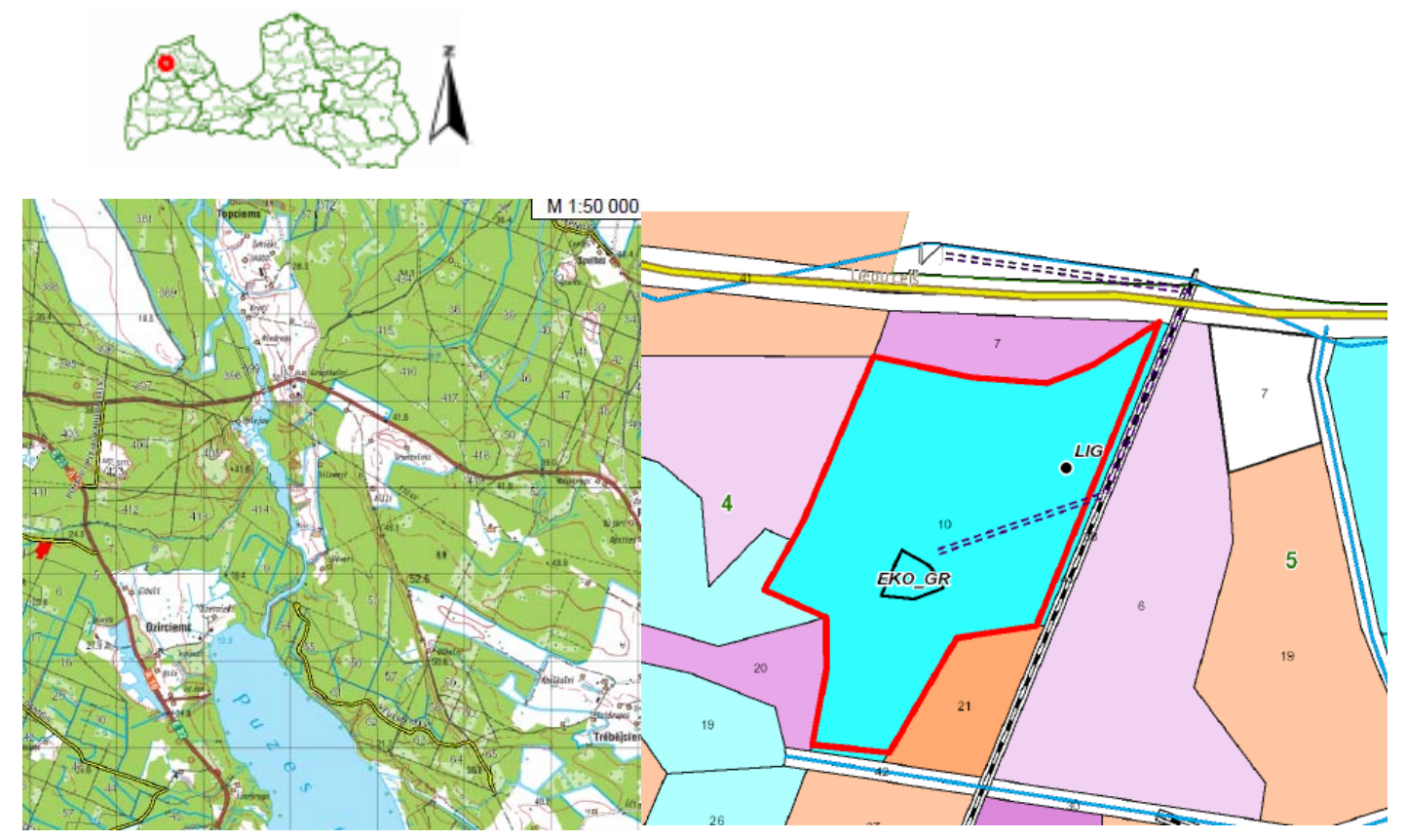

Fig. 3. Wood felling area and the technological scheme of harvesting

The typical shape of spruce stem in wood felling area is shown (Fig.4.)

After harvesting each log was manually measured with a caliper and a ruler for its diameter and lenght. The sequent log parameters were measured: D butt. max. sob. (mm); D butt. average sob. (mm); D 0.5 sob. (mm); D1.0 sob. (mm); D top. sob. $(\mathrm{mm})$; butt swelling $(\mathrm{cm} / \mathrm{m})$; taper $(\mathrm{mm})$. All logs were numbered to facilate the identification. After this measurement all $55 \operatorname{logs}$ were measured once more to determine the accuracy and repeatability of the manual measurement. This action was made by other scaller. The diameters were measured on bark but the volumes of roundwood assortiments measured on bark were estimated without bark by using the formula (1) (Fig.9.).

For spruce roundwood assortiments the double bark thickness at the point of measuring were determined:

$$
\mathrm{B}=3,08+0,0404 \mathrm{xD}
$$

The following procedures were used to achieve the required objective:

1. To control the measurement accuracy of manual, automatic measuring (caliper, girthing tape to measure circumference, log measuring ruler, automatic device etc.)according to requirements of standard LVS 82:2003, to requirements of model of volume calculation developed for Swedish roundwood (Anon 2000) and technical requirements for automatic and harvester measuring systems (Ktr-file). where: $\mathrm{D}$ - diameter of roundwood assortiment, $\mathrm{mm}$.

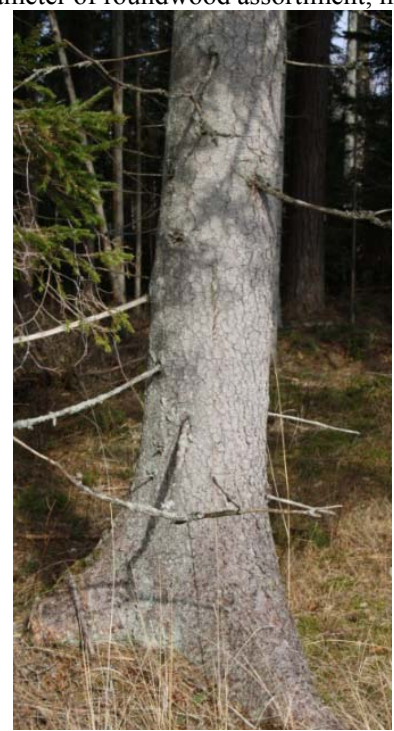

Fig. 4. The typical shape of spruce stem in wood felling area (As)-Myrtillosa mel.

2. To identify the spruce stems before harvesting and to measure the parameters of identified stems according to scheme (Fig. 5.)

3. To identify the first logs after harvesting and to measure the dimension parameters according to the scheme (Fig. 5.)

4. To collect and to analyse the harvester mesurement Prd- file and Pri-file data in connection with manually measured parameters of logs. 
5. To measure the identified logs in sawmill by measuring diameter in short intervals using electronic 3D systems.

6. To calculate the volume of logs according to the top and butt diameter measurements methods according to requirements of standard LVS 82:2003 and by model of volume calculation developed for Swedish roundwood (Anon 2000) (Fig.5.)

7. To analyse the measurement deviations.

8. To control the algorithm of the volume calculation in each technological stage of roundwood processing.

9. To determine the dependences between the volume of $\operatorname{logs}$ determined by automatic devices and results of manual comparative measurement methods.

10. To give the recommendations for the most appropriate manual measurement method which provide the least wood volume deviation comparing to the results given by harvester and electronic measurement.

All calibrated measuring devices ensured measuring accuracy appropriate to requirements of standard LVS 82:2003 and the technical requirements for automatical and harvester measuring systems (Fig.6.; Table 1.).The length was determined with an accuracy $1 \mathrm{~cm}$ for manual and automatical measurement devices and $3 \mathrm{~cm}$ for harvester measuring devices; the diameter was determined with an accuracy $1 \mathrm{~mm}$ for manual and automatical measurement devices and $3 \mathrm{~mm}$ for harvester measuring devices.

Harvester measurement accuracy were assessed through comparison with manual log measurements and volume calculation where volume standard deviation was $0.06 \%$ (Fig.6.)

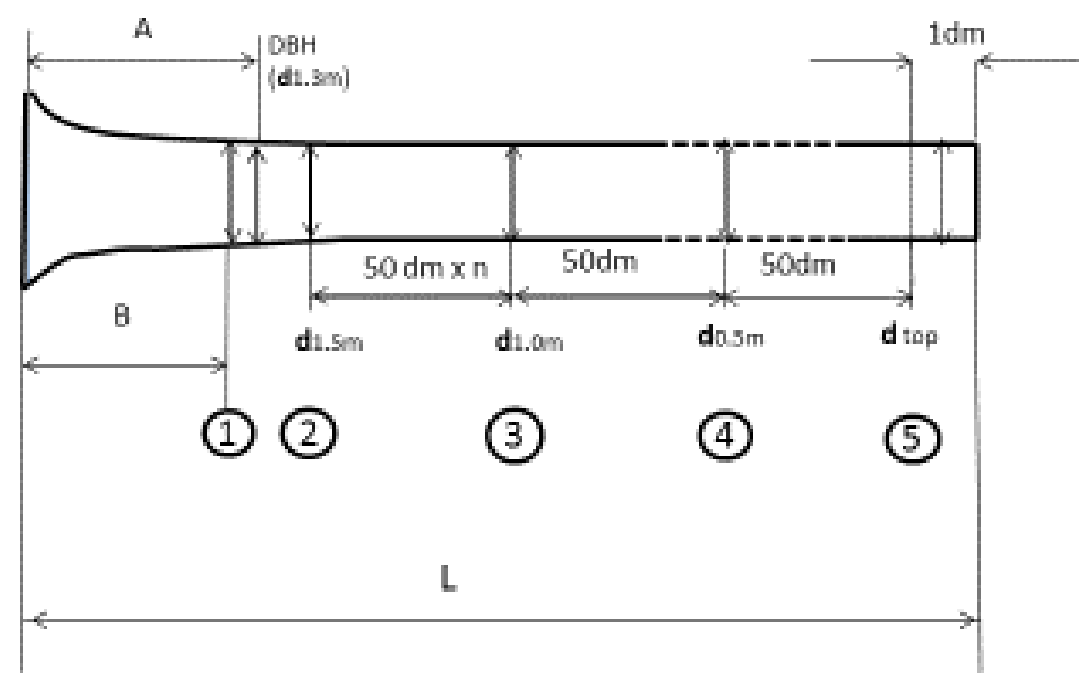

Fig.5. The scheme of the measuring points of the roundwood assortiment based on manual control (operator) measurements with caliper, where: A - the first measuring point $\mathrm{DBH}(\mathrm{d1} .3 \mathrm{~m})$ done by harvester measuring system for butt diameter prediction $(\mathrm{A}=130 \mathrm{dm}), \mathrm{B}-\mathrm{the}$ first manual measuring point to control the harvester accuracy for the first log of stem : John Deer $(B=120 \mathrm{dm})$; Ponse $(B=50$ or $120 \mathrm{dm})$; TimberJack $(\mathrm{B}=120 \mathrm{dm})$ 


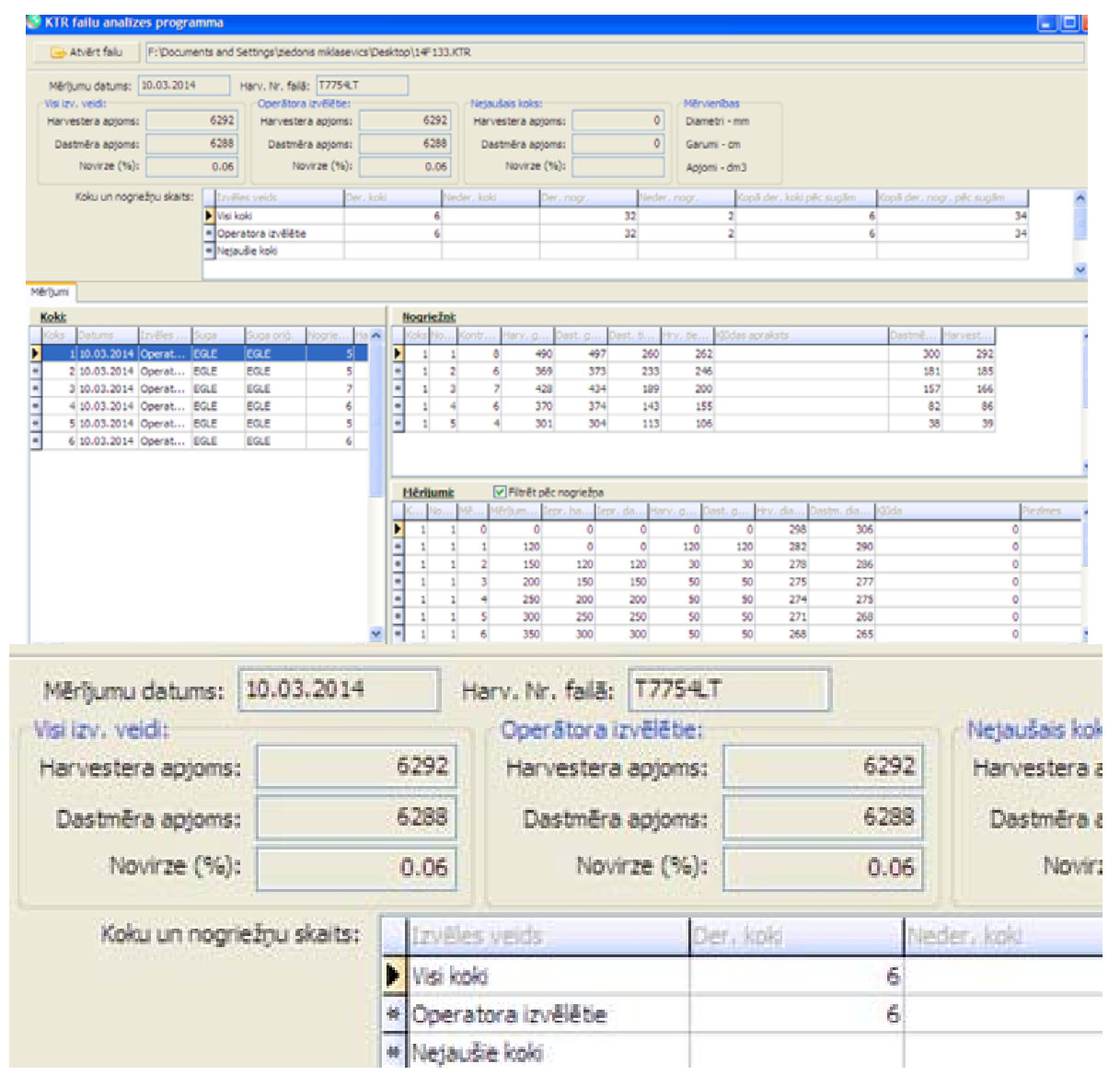

Fig.6. The result of control of harvester measuring system, where 6 control stems, 34 round wood assortiments, 96 diameter were measured. Standard deviation is $0.06 \%$

For volume estimation the sequent measuring methods were applied (Fig. 8) by using manual measuring equipment, harvester measuring system (harvester John Deer 1270; harvester head HD 758; measuring equipment TimbermaticH 300; caliper version: SKALMAN 5.16) and automatical measuring system (3D scanner Mikropuu Oy (FIN) OPMES 604/614 


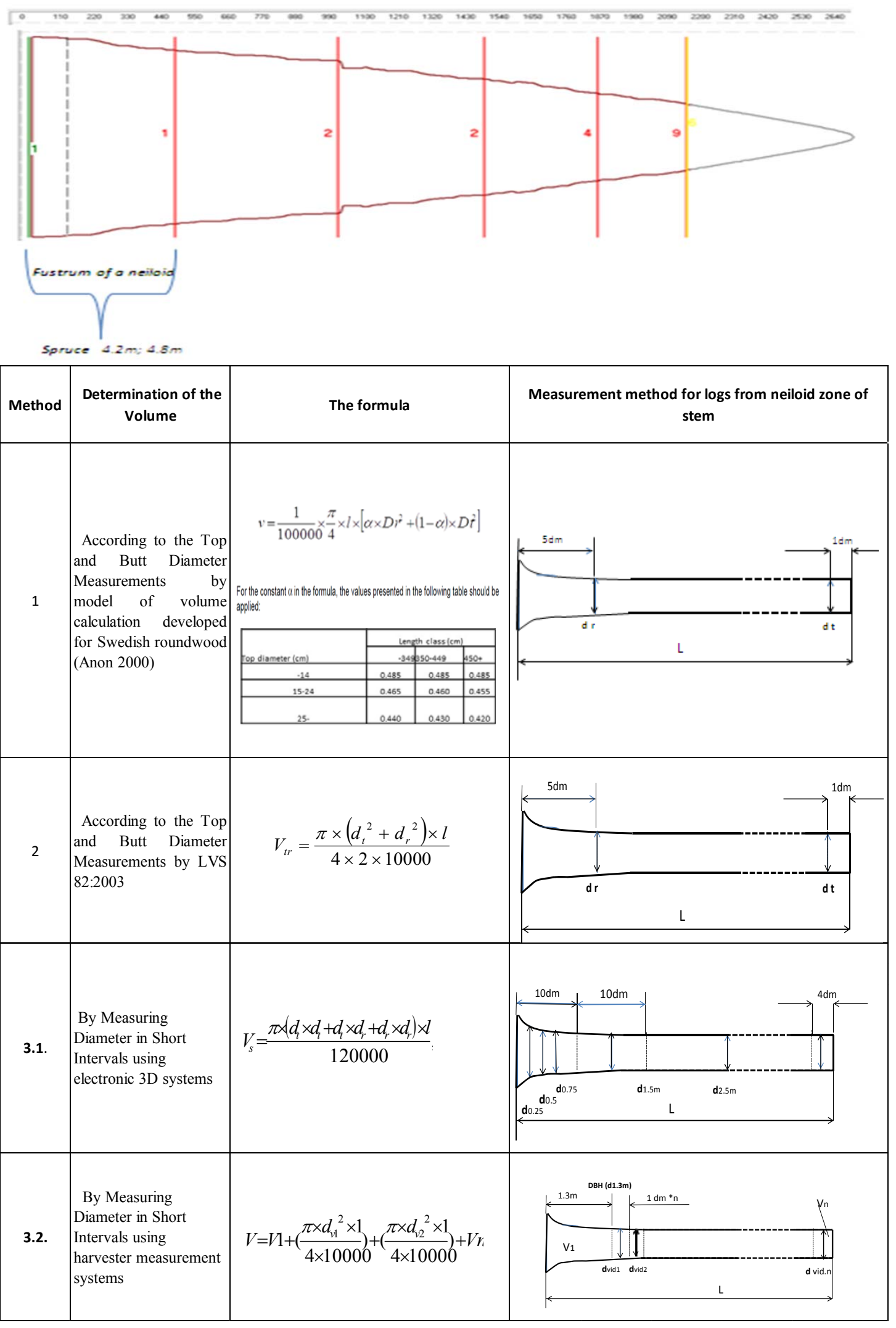

Fig.7. Measuring methods applied in investigation for roundwood assortiments from neiloid zone of stem, where $\mathrm{L}=4.2 \mathrm{~m} ; 4.8 \mathrm{~m}$ 
TABLE 1

The control results of the 3D scanner Mikropuu Oy (FIN) OPMES 604/614

\begin{tabular}{|c|c|c|c|c|}
\hline Etalon Nr. & $\mathbf{5 1 0 1 1 6 3 0}$ & $\mathbf{5 1 0 1 1 7 3 0}$ & $\mathbf{5 1 0 1 1 8 3 0}$ & \multirow{2}{*}{ Accepted, $\mathrm{mm}$} \\
\hline Etalon diameter, $\mathrm{mm}$ & 110,3 & 200,7 & 315,5 & \pm 1 \\
\hline Average, $\mathrm{mm}$ & 0.6 & -0.5 & -0.8 & +2 \\
\hline Standard deviation, $\mathrm{mm}$ & 0.1 & 0.18 & 0.21 & -2 \\
\hline Maximal positive, $\mathrm{mm}$ & 1.0 & -0.3 & -0.5 & -1.3 \\
\hline Maximal negative, $\mathrm{mm}$ & 0.2 & -0.8 & & \\
\hline
\end{tabular}

\section{RESULTS AND DISCUSSION}

The characteristics of the roundwood assortiments according to the manual piece-by-piece measurement are given in the Table 2 .

The volume values of spruce roundwood assortiments from neiloid zone of stems were calculated according to the measuring methods applied in investigation for logs from neiloid zone of stem (Fig. 7.) by using manual measuring equipment, harvester measuring system (harvester T1386LH; measuring equipment TimbermaticH 1.13.14.; caliper version: SKALMAN 5.16) and automatical measuring system (3D scanner SAWCO POS A181). The results were compared with the volume values calculated according to the Top and Butt Diameter Measurements by model of volume calculation developed for Swedish roundwood (Anon 2000). The measurement and volume results are given (Fig. 9; 10; 11).
TABLE 2

The characteristics of the roundwood assortiments

\begin{tabular}{|l|l|}
\hline Variable & Parameters \\
\hline $\begin{array}{l}\text { Number of roundwood } \\
\text { assortiments }\end{array}$ & 55 \\
\hline $\begin{array}{l}\text { Amount of butt assortiments } \\
(\%)\end{array}$ & 100 \\
\hline Top diameter $(\mathrm{mm})$ & \\
\hline Average & 235 \\
\hline Std & 2 \\
\hline Butt diameter $(\mathrm{mm})$ & \\
\hline Average & 337 \\
\hline Std & 3 \\
\hline D 1.0 (mm) & \\
\hline Average & 279 \\
\hline Std & 2 \\
\hline D 0.5 $(\mathrm{mm})$ & \\
\hline Average & 262 \\
\hline Std & 4 \\
\hline Butt swelling $(\mathrm{cm} / \mathrm{m})$ & \\
\hline Average & 7 \\
\hline Std & 0.1 \\
\hline Taper $(\mathrm{cm} / \mathrm{m})$ & \\
\hline Average & 0.7 \\
\hline Std & 0.03 \\
\hline & \\
\hline
\end{tabular}



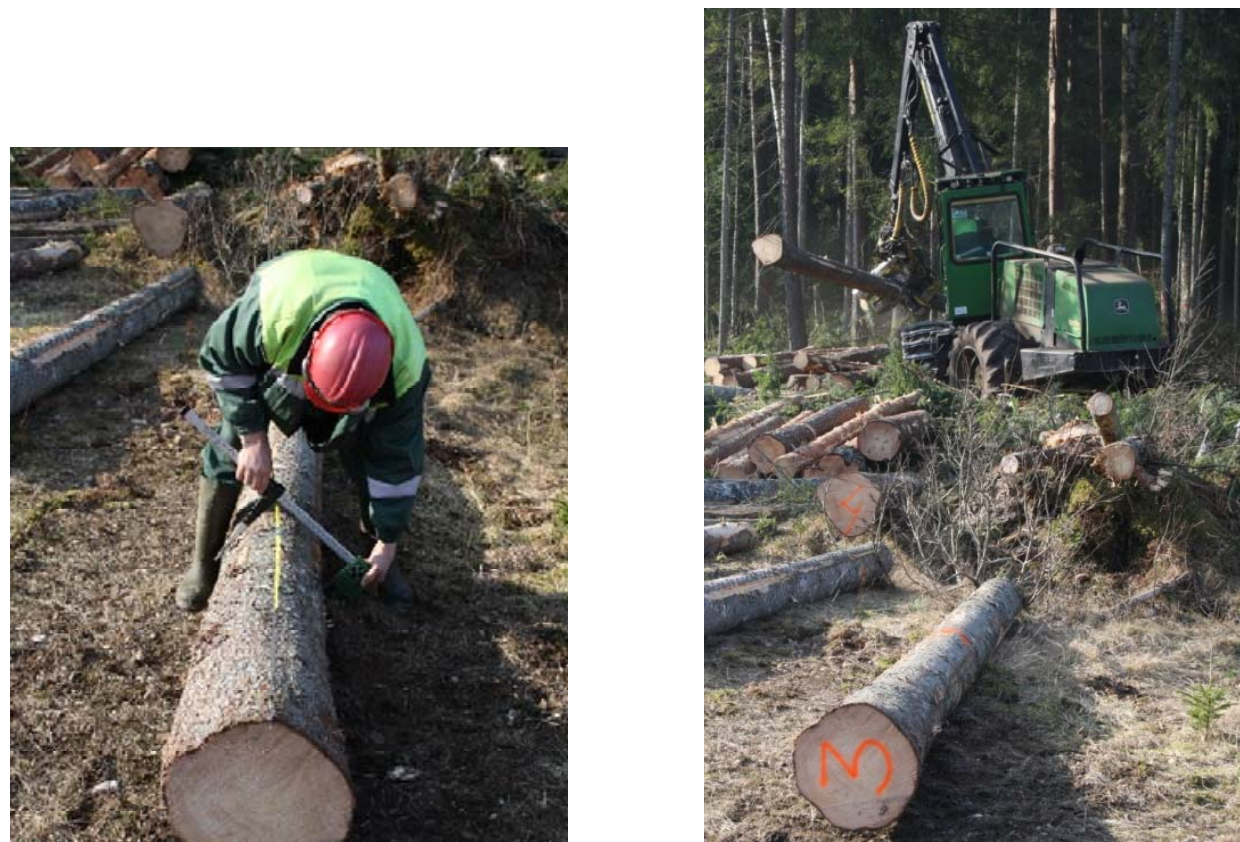

Fig. 8. The example of control of the harveaster measuring system, where:

the $\log \mathrm{N}^{\mathrm{o}} 3$ participated one of the 34 round wood assortiments used in the process of control of harvester measuring system

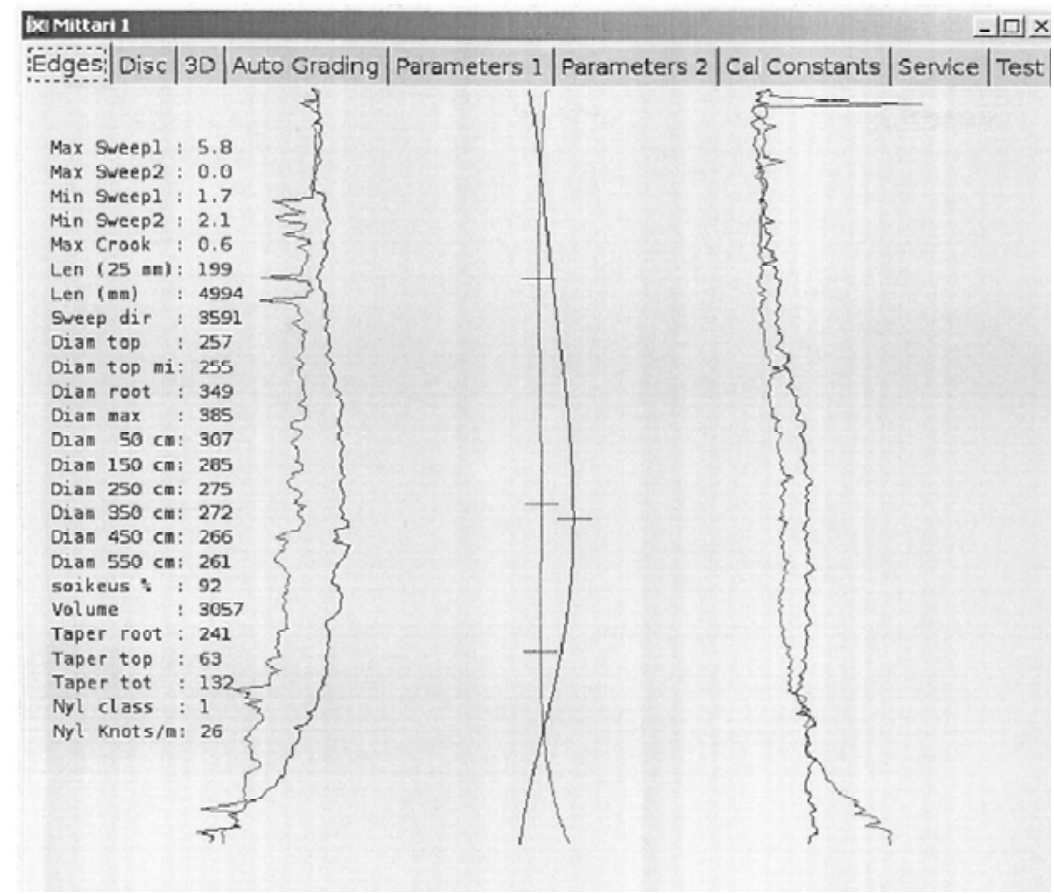

Fig.9. The measurement parameters of the sample $\mathrm{N}^{\circ} 3$ (Fig.8.) by measuring diameter in short intervals using electronic 3D systems 


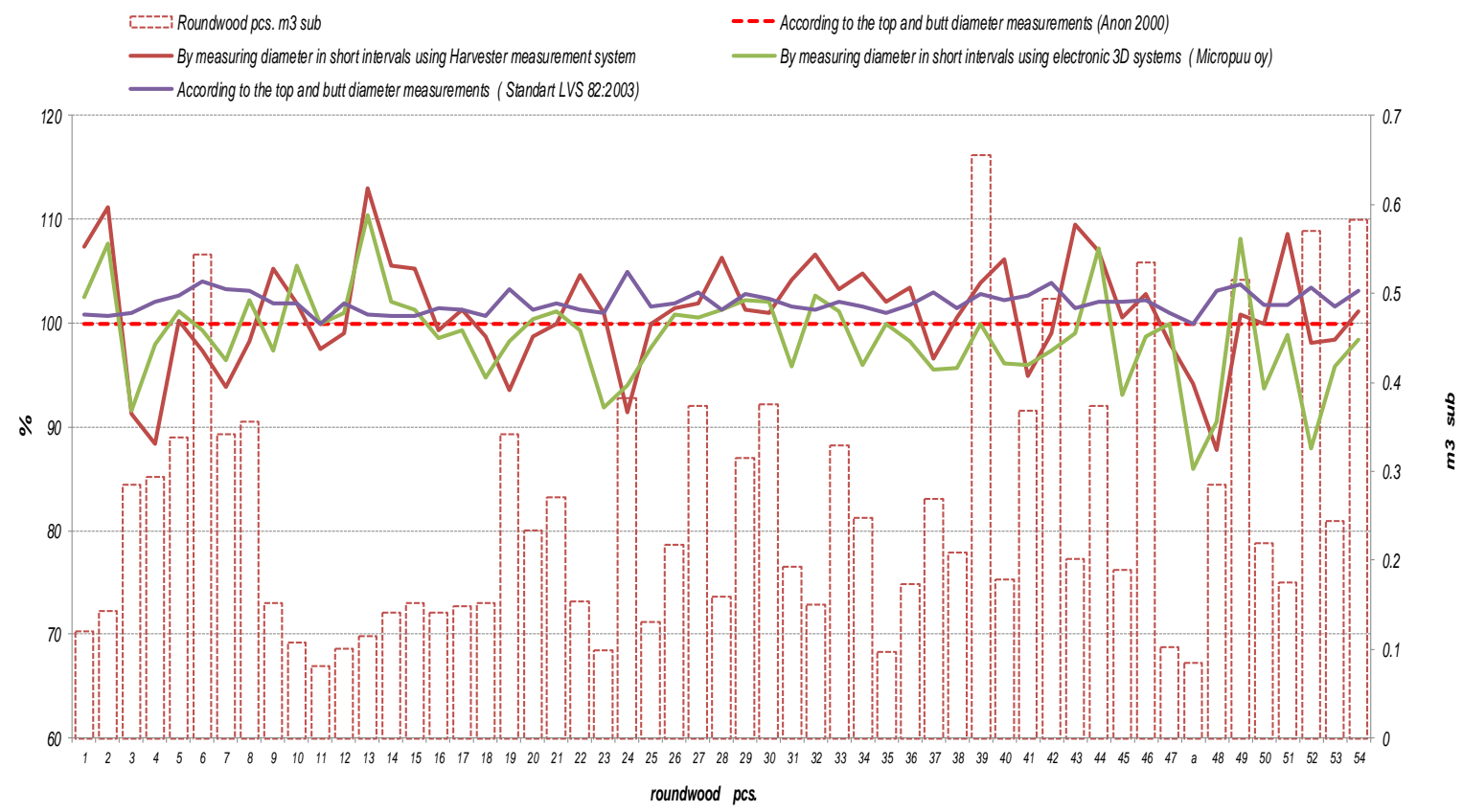

Fig.10 The volume results of spruce roundwood assortiments from neiloid zone of stems estimated according to measuring methods applied in investigation

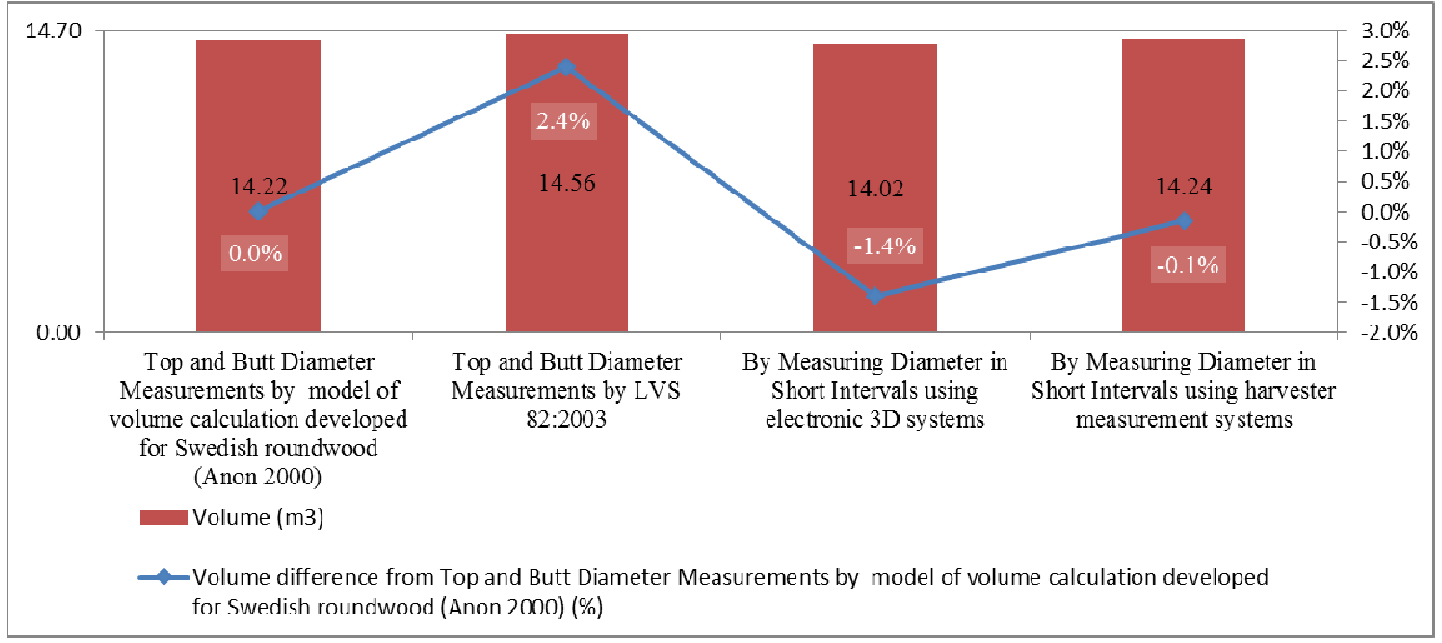

Fig.11. Roundwood load volume comparison using different measuring methods

a. The results of measuring are sequential:

The volume of roundwood assortiments determined according to the Top and Butt Diameter Measurements by model of volume calculation developed for Swedish roundwood (Anon) was 2.4\% lower than the volume determined by the Top and Butt Diameter Measurement method (LVS 82:2003).

The volume of roundwood assortiments determined according to the Top and Butt Diameter Measurements by model of volume calculation developed for Swedish roundwood (Anon) was 1.4\% lower than the volume determined by Measuring Diameter in Short Intervals using electronic 3D systems.
The volume of roundwood assortiments determined according to the Top and Butt Diameter Measurements by model of volume calculation developed for Swedish roundwood (Anon) was $0.1 \%$ lower than the volume determined by Measuring Diameter in Short Intervals using harvester measurement systems.

$b$. The results of of multiple regression analyse are sequential:

The results of multiple regression analyse between measurement diference (\%)measured manually (according to requirements of standard LVS 82:2003 and to requirements of model of volume calculation developed for Swedish roundwood (Anon 2000)), butt 
swelling $(\mathrm{cm} / \mathrm{m})$ and taper $(\mathrm{cm} / \mathrm{m})$ are given in the Table 3 .

TABLE 3

Multiple regression analyse

\begin{tabular}{|c|c|c|c|}
\hline & Butt swelling $(\mathrm{cm} / \mathrm{m})$ & Measurement difference (\%) & Taper $(\mathrm{cm} / \mathrm{m})$ \\
\hline Butt swelling $(\mathrm{cm} / \mathrm{m})$ & 1 & & \\
\hline Measurement difference (\%) & 0.597656954 & 1 & \\
\hline Taper $(\mathrm{cm} / \mathrm{m})$ & 0.349620121 & 0.565747656 & 1 \\
\hline
\end{tabular}

The correlation between measurement difference (\%)measured manually (according to requirements of standard LVS 82:2003 and to requirements of model of volume calculation developed for Swedish roundwood (Anon 2000)) and butt swelling $(\mathrm{cm} / \mathrm{m})$ is an average firm $r=0.597656954$.

The correlation between measurement difference (\%)measured manually (according to requirements of standard LVS 82:2003 and to requirements of model of volume calculation developed for Swedish roundwood (Anon 2000)) and taper $(\mathrm{cm} / \mathrm{m})$ is an average firm $\mathrm{r}=0.565747656$.

The correlation between butt swelling $(\mathrm{cm} / \mathrm{m})$ and taper $(\mathrm{cm} / \mathrm{m})$ is weak $\mathrm{r}=0.349620121$.

The correlation between measurement diference (\%) and taper $(\mathrm{cm} / \mathrm{m})$ is an average firm $r=0.565747656$. Standard error of the regression coefficient $\mathrm{r}=0.565747656$ is $\mathrm{s}_{\mathrm{r}}=0.1132$

The actual value of the test $\mathrm{t}=4.9948$; the critical value of the test $t_{\alpha v}=t_{0.05 ; 53}$ indicating the number of degrees of freedom to characterize the distribution. The formula result is (-)1.67412. It shows that with a $95 \%$ confidence the multicollinearity is existing between features because of $/ \mathrm{t} /=4.9948>\mathrm{t}_{0.05 ; 53}=(-$ )1.6741.

The correlation between measurement diference (\%) and butt swelling $(\mathrm{cm} / \mathrm{m})$ is an average firm $\mathrm{r}=0.597656954$. Standard error of the regression coefficient $r=0.597656954$ is $\mathrm{s}_{\mathrm{r}}=0.1101$. It shows that with a $95 \%$ confidence the multicollinearity is existing between features because of

$$
/ \mathrm{t} /=5.4268>\mathrm{t}_{0.05 ; 53}=(-) 1.6741 .
$$

\section{CONSLUSION}

To increase the accuracy of volume values, to decline the commercial profability and to remove diferences originating among particular procedures of measurements it is proposed:

to base manual measuring on determination of the volume of spruce roundwood assortiments from neiloid zone of stem according to to the top and butt diameter measurement method according to requirements of volume calculation developed for Swedish roundwood (Anon 2000), to base harvester measuring system algorithm on functions defined in spp file (Räsänen, 2007.), in sawmils to determine the volume by measuring diameter in short intervāls using electronic 3D systems.

\section{REFERENCES}

[1] Apalo kokmateriālu uzmērīšana. LVS 82:2003.

[2] Anon 2000. Kompendium i virkesmätning. Virkesmätningsrådet, SDC, Sundvall.

[3] Černy, M.; Parez, J. (1995) Tables and rational functions for calculation of log volume under bark. Praha Finland

Ministry of Agriculture and Forestry.(1997) Roundwood Volume Measurement Standards [Reg 918/66/97]. [Online]. Available: http://www.finlex.fi/data/normit/1259002074fil.pdf.[Accesed: October 16, 2012].

[4] Janak, K (2005) Differences in volume of round Timber caused by different determination methods Drvna industrija 56 (4) pp.165-170.

[5] Janak, K. (2007) Differences in roundwood measurements using electrinic 2D and 3D systems and Standard manual method Drvna industrija Vol 58 (3) pp.127-133.

[6] Miklasevics, Z. (2013) Harmonization of piece-by-piece measurement methods of roundwood approved by Latvian standard LVS 82:2003 "Apalo kokmateriālu uzmērǐsana".ISSN 1691-5402. Environment. Technology. Resources. Proceedings of the $9^{\text {th }}$ international conference reports, Rezekne, 2013.

[7] Patterson, D.W., Wiant, H.V. Jr. and Wood, G.B. Errors in estimating the volume of butt logs. For. Prod.J. 43(3); 1-4

[8] Patterson, D.W., Wiant, H.V. Jr. and Wood, G.B. Comparison of the centroid method and taper systems for estimating tree volume, Hthn J. Appl. For. 10 (1): 8-9

[9] Patterson, D.W., Wiant, H.V. Jr. and Wood, G.B. Log volume estimations: The centroid method and standard formulas. J.For.91: 39-41.

[10] Round and sawn timber - Method of measurement of dimensions - EN 1309-2. Part2: Round timber - Requirements for measurement and volume calculation rules. (2006) Brussels

[11] The Swedish Timber Measurement Council. 1999. Regulations for Measuring of Roundwood (Circular VMR 1-99). Sweden.

[12] Wood,G.B. and Wiant, H.V. (1995) Modern methods of estimating tree and log volume, Proc.IUFRO Conference, Morgantown, West Virginia. West Virginia University Publication Services. p.168.

[13] Räsänen, T., Poikela, A., Arlinger, J. (2007) Spp-file in StanForD. http://www.skogforsk.se/en/Aboutskogforsk/Collaboration-groups/StanForD/StandardDocuments/

[14] Fonseca, M. A. 2005. The Measurement of Roundwood: Methodologies and Conversion Ratios. CABI Publishing, Wallingford, Oxfordshire, United Kingdom.

[15] Finland Ministry of Agriculture and Forestry. 1997. Roundwood Volume Measurement Standards [Reg918/66/97]. Available at: http://www.finlex.fi/data/normit/12590-02074fil.PDF 
Ziedonis Miklašêvičs / Environment. Technology. Resources, (2015), Volume II, 207-218

[16] National Council for Forest Resources and Development (COFORD). 2000. Timber Measurement Manual - Standard
Procedures for the Measurement of Round Timber for Sale Purposes in Ireland. COFORD. Dublin, Ireland. 